\title{
Nature and origin of volcanic ash in the 2000 eruption of Usu volcano, southwestern Hokkaido, Japan
}

\author{
Kenji Nogami ${ }^{1}$, Jun-ichi Hirabayashi ${ }^{1}$, Yuichi Nishimura ${ }^{2}$, and Atsuo Suzuki ${ }^{2}$ \\ ${ }^{1}$ Volcanic Fluid Research Center, Tokyo Institute of Technology, Kusatsu, Agatsuma, Gunma 377-1711, Japan \\ ${ }^{2}$ Institute of Seismology and Volcanology, Hokkaido University, Tatsuka, Sobetsu, Hokkaido 052-0106, Japan
}

(Received December 14, 2001; Revised September 20, 2002; Accepted September 27, 2002)

\begin{abstract}
Usu volcano, one of the most active volcanoes in Japan, erupted at regular intervals of ca. 30 years during the 1900s. The 2000 eruption took place on March 31 following 23 years of dormancy. An increase in seismic activity and remarkable ground deformation preceded the eruption. Many small-scale craters were successively formed in two areas at the foot of the volcano and ash was ejected intermittently from them. Ten samples out of the 2000 ash collected around the volcano during half a year were analyzed. They were depleted in $\mathrm{SiO}_{2}$ but enriched in $\mathrm{FeO}$ compared with the essential ejecta of the five major historic eruptions and all were highly altered as a whole. XRD analysis revealed smectite as a major clay mineral in the ash and kaolin as a minor one. The clay mineral assemblage and the trend of change in chemical composition of the 2000 ash are quite similar to those of the 1977-1978 ash. No temporal changes in chemical composition and clay mineral assemblage of the 2000 ash were detected. The percentages of the LOI and the relative proportions of $\mathrm{SiO}_{2}$ in the ashes and the essential ejecta showed a linear correlation. These results indicate that the constituents of the 2000 ash were alteration products of the volcaniclastics of the historic eruptions in the subsurface.
\end{abstract}

\section{Introduction}

Natural occurrences of clays and secondary minerals disclose geological settings and alteration environments (e.g. Ossaka, 1968; Ossaka and Hirabayashi, 1981; Ylagan et al., 1996). Clay minerals such as smectite, kaolin, halloysite, pyrophyllite and secondary minerals such as gypsum and pyrite are common in the fine fraction of volcanic ash from many volcanoes in Japan (e.g. Ossaka and Ozawa, 1966; Matsuo et al., 1977: Ossaka, 1982; Hirabayashi et al., 1996; Nogami et al., 2000). Chemical compositions and mineral assemblage of alteration products in the volcanic ash can thus provide information on chemical conditions inside volcanoes.

Usu volcano, one of the most active volcanoes in Japan, is located in southwestern Hokkaido (Fig. 1). It erupted on March 31, 2000 after 23 years of dormancy. Many craters were formed and ash was ejected intermittently from them. In this paper, we describe the nature and origin of the 2000 ash based on its chemical composition and clay mineral assemblage.

\section{Brief History of the Usu Volcano and Volcanic Activity in $\mathbf{2 0 0 0}$}

The Usu volcano consists of many dacitic lava domes and cryptodomes. It has erupted every $30-50$ years during the last three centuries with dome formation sometimes accompanying pyroclastic flows. In the last century, big eruptions occurred in 1910, 1943-1945 and 1977-1978 and Yosomiyama, Showa Shinzan, Ko-Usu and O-Usu lava

Copy right (C) The Society of Geomagnetism and Earth, Planetary and Space Sciences (SGEPSS); The Seismological Society of Japan; The Volcanological Society of Japan; The Geodetic Society of Japan; The Japanese Society for Planetary Sciences. domes were formed (e.g. Katsui et al., 1978). The regularity of these eruptions has been noticed to predict eruptions (e.g. Yokoyama et al., 1973).

Numerous wells yielding neutral $\mathrm{pH}$ and weakly alkaline hot water are distributed over the northern foot of the volcano. They are regarded as having been formed during postvolcanic activity after the 1910 eruption (Ishikawa, 1963). Geothermal and fumarolic activity has continued between the Ko-Usu and O-Usu lava domes and the Gin-numa crater within the summit crater since the previous eruption in 19771978 (Fig. 1).

Seismic activity beginning on March 27, 2000 was followed by numerous earthquakes many of which were felt in the region around the volcano. The GPS network of the Geographical Survey Institute surrounding the volcano detected ground deformation from March 28. Many new cracks and faults, which were formed in and around the volcano, greatly disrupted roads and structures. The 2000 eruption began at 13:10 on March 31. Initial explosions took place at the western foot of Nishiyama with successive formation of new craters. Another eruption began at 11:00 on April 1 at the western foot of Konpirayama located at about $1 \mathrm{~km}$ northeastward from the new Nishiyama craters (Ui and Geological party, Joint Obs. team, 2000; Mori and Ui, 2000). The formation of new craters in the two areas lasted for about one week from the beginning of the eruption. After that, no new craters formed but gases continued to discharge sometimes with small amount of the ash from some craters.

The dormant period of 23 years since the last activity in 1977-1978 is shorter than any other known. The 2000 eruption was successfully predicted based on its precursory seis- 

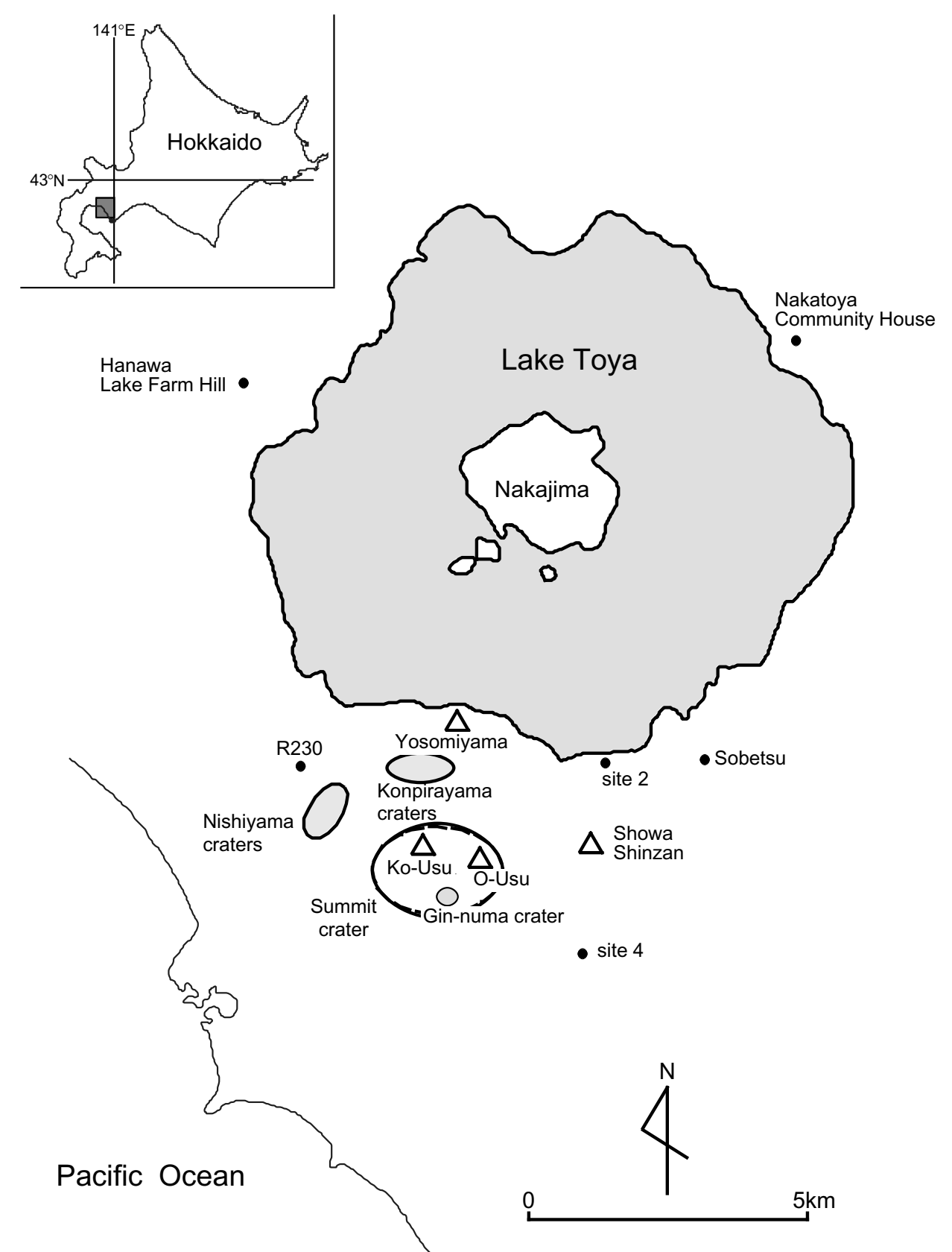

Fig. 1. Map showing the locations of sampling sites of the ashes, the Nishiyama and Konpira new craters and the major domes, Ko-Usu, O-Usu and Showa Shinzan formed by the historic eruptions.

mic activity and the ground deformation (Okada et al., 2000). Prior to the eruption, more than sixteen thousand residents were evacuated from hazardous areas near the volcano but there were no casualties.

\section{Sampling and Analytical Procedure}

Ash collectors were stationed around the volcano from April 2 (Fig. 1). Ash was also collected from leaves, plastic sheets and paper sheets in the neighborhood of the new craters. The ash was ejected from several craters so all the 2000 ash was not derived from a single one.

Grain size analysis by sieving was made on the April 2, 4 and 6 ashes that were abundantly collected. Particles from $250 \mu \mathrm{m}$ to $500 \mu \mathrm{m}$ and those finer than $250 \mu \mathrm{m}$ comprised $30 \%$ and $70 \%$ of the ash collected on April 2, respectively.
The April 5 and April 6 ashes were composed of particles finer than $250 \mu \mathrm{m}$. Although the ash collected from the middle of April was not enough for grain size analysis, this ash did not contain particles apparently coarser than $500 \mu \mathrm{m}$ and it was uniformly fine-grained.

The chemical compositions of the 2000 ash were determined by X-Ray Fluorescence spectrometry (XRF) using glass beads with 10 parts flux to one part sample dried at $110^{\circ} \mathrm{C}$ for 24 hours. Weight loss on ignition (LOI) of the ash was determined by gravimetry.

Constituent clay minerals of the ash were determined by X-Ray Diffraction (XRD). The bulk ash particles were loaded into a glass holder after being ground in an agate mortar. The fine fractions of three samples were obtained by centrifuging after fractionation by sedimentation. The clay ag- 
Table 1. Chemical composition of the 2000 ash from Usu volcano.

\begin{tabular}{|c|c|c|c|c|c|c|c|c|c|}
\hline Date & Mar. 31 & Apr. 2 & Apr. 3 & Apr. 4 & Apr. 4 & Apr. 6 & May 7 & Jun. 1 & Sep. 26 \\
\hline Loc. & $\mathrm{R} 230$ & O-usu & Site 4 & Nakatoya & Hanawa & Sobetsu & Site 2 & Site 2 & Konpira \\
\hline \multicolumn{10}{|c|}{ Components in wt $\%$} \\
\hline $\mathrm{SiO}^{2}$ & 60.85 & 59.27 & 54.28 & 56.57 & 55.45 & 57.97 & 58.39 & 55.18 & 56.02 \\
\hline $\mathrm{TiO}_{2}$ & 0.74 & 0.98 & 0.87 & 0.83 & 0.88 & 0.82 & 0.70 & 0.82 & 0.86 \\
\hline $\mathrm{Al}_{2} \mathrm{O}_{3}$ & 17.75 & 20.31 & 18.65 & 18.47 & 18.95 & 17.62 & 15.58 & 19.54 & 20.05 \\
\hline $\mathrm{FeO}^{*}$ & 7.20 & 9.28 & 8.92 & 8.02 & 8.51 & 8.21 & 7.17 & 8.71 & 9.18 \\
\hline $\mathrm{MnO}$ & 0.17 & 0.22 & 0.21 & 0.18 & 0.19 & 0.17 & 0.17 & 0.17 & 0.17 \\
\hline $\mathrm{MgO}$ & 1.93 & 2.31 & 2.31 & 2.19 & 2.30 & 2.04 & 3.02 & 2.48 & 2.48 \\
\hline $\mathrm{CaO}$ & 4.77 & 6.30 & 6.69 & 5.63 & 5.84 & 5.50 & 7.20 & 6.76 & 5.01 \\
\hline $\mathrm{Na}_{2} \mathrm{O}$ & 2.47 & 1.56 & 1.64 & 1.80 & 1.54 & 1.93 & 2.15 & 1.95 & 1.87 \\
\hline $\mathrm{K}_{2} \mathrm{O}$ & 0.76 & 0.48 & 0.50 & 0.59 & 0.54 & 0.72 & 0.98 & 0.55 & 0.55 \\
\hline $\mathrm{P}_{2} \mathrm{O}_{5}$ & 0.14 & 0.14 & 0.12 & 0.14 & 0.14 & 0.14 & 0.10 & 0.11 & 0.09 \\
\hline Total & 96.77 & 100.83 & 94.20 & 94.42 & 94.33 & 95.11 & 95.45 & 96.27 & 96.28 \\
\hline $\mathrm{Cl} \mathrm{SW}^{* *}$ & 209 & 560 & 801 & 483 & 573 & 531 & 14.3 & 1160 & 89.6 \\
\hline $\mathrm{SO}_{4} \mathrm{SW}^{* *}$ & 1430 & 2410 & 3560 & 4270 & 4060 & 3000 & 84.6 & 2730 & 1214 \\
\hline $\mathrm{LOI}^{* * *}$ & 6.47 & 12.61 & 11.68 & 11.45 & 12.92 & 8.38 & 5.50 & 8.18 & 9.24 \\
\hline
\end{tabular}

$\mathrm{FeO}^{*}$ :total iron as $\mathrm{FeO} \mathrm{SW}{ }^{* *}$ : soluble in water in $\mathrm{mg} / \mathrm{kg} \mathrm{LOI}^{* * *}$ : weight loss on ignition in \% LOI is a percentage of the weight loss on ignition without correction for oxidation of $\mathrm{FeO}$ to $\mathrm{Fe}_{2} \mathrm{O}_{3}$.

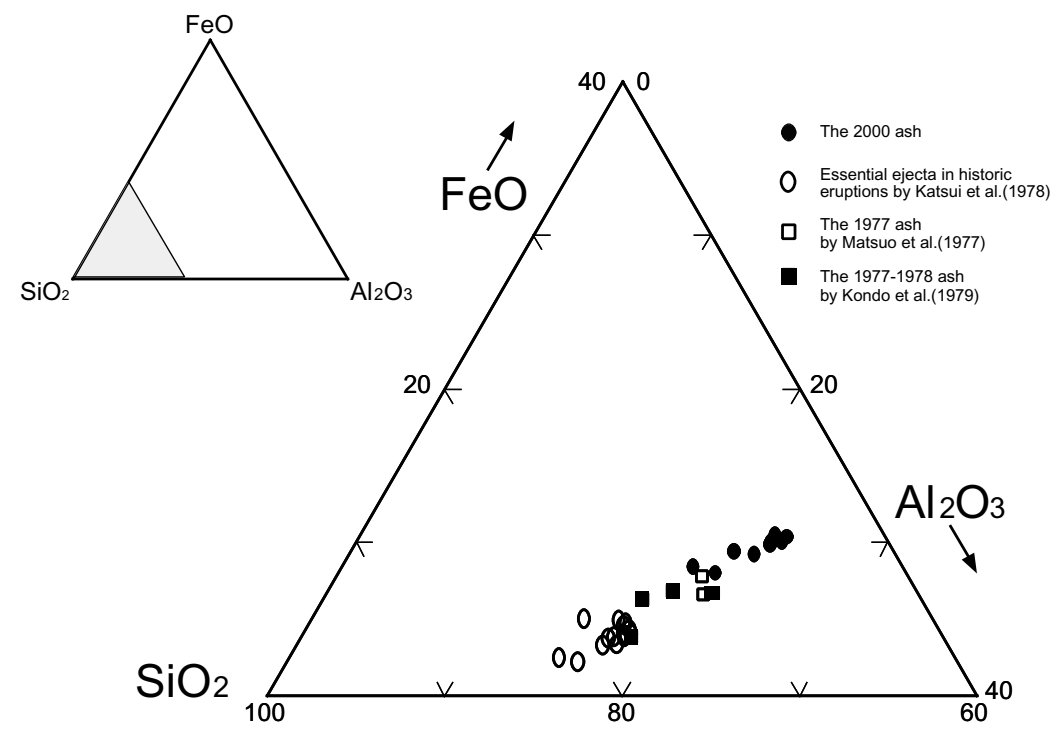

Fig. 2. Relative proportions of $\mathrm{SiO}_{2}, \mathrm{Al}_{2} \mathrm{O}_{3}$ and $\mathrm{FeO}$ in the ashes and the essential ejecta of the historic eruptions of Usu volcano.

gregates were oriented onto glass slides and air-dried at room temperature. These samples were $\mathrm{X}$-rayed by $\mathrm{Ni}$-filtered $\mathrm{Cu}-$ $\mathrm{K} \alpha$ radiation from $2^{\circ}$ to $25^{\circ} 2 \theta$ at scan speeds of $0.02^{\circ} 2 \theta$ per second. The fine fractions were subjected to XRD analysis after ethylene glycol solvation and heating at $600^{\circ} \mathrm{C}$ for one hour.

\section{Results and Discussion}

The chemical compositions of the 2000 ash are listed in Table 1. High values of LOI given in Table 1 suggest that all the 2000 ash samples are highly altered. Small amounts of essential fragments and small pumice were found only in the ash collected on March 31 and April 1, 2000 (Mori and Ui, 2000). Considerable amounts of water-soluble components adhered to the 2000 ash as listed in Table 1, however, their contents are less than those of LOI.

Relative proportions of $\mathrm{SiO}_{2}, \mathrm{Al}_{2} \mathrm{O}_{3}$ and $\mathrm{FeO}$ in the 2000 ash are shown in Fig. 2. The proportions of the 1977-1978 ash (Matsuo et al., 1977; Kondo et al., 1979) and essential ejecta of the historic eruptions (Katsui et al., 1978) are also plotted on the same figure. The 1977-1978 ash is depleted in $\mathrm{SiO}_{2}$ but enriched in $\mathrm{FeO}$ compared with the essential ejecta of the historic eruptions. The 2000 ash is further depleted in $\mathrm{SiO}_{2}$ but enriched in $\mathrm{FeO}$ compared with the 1977-1978 ash.

XRD patterns of the bulk ash commonly show a broad peak at $14 \AA$ and a minor peak at $7 \AA$ (Fig. 3). The fine fractions of the 2000 ash consist of the same minerals, as shown in Fig. 4. Reflections at $14 \AA$ expanded to $17 \AA$ upon 


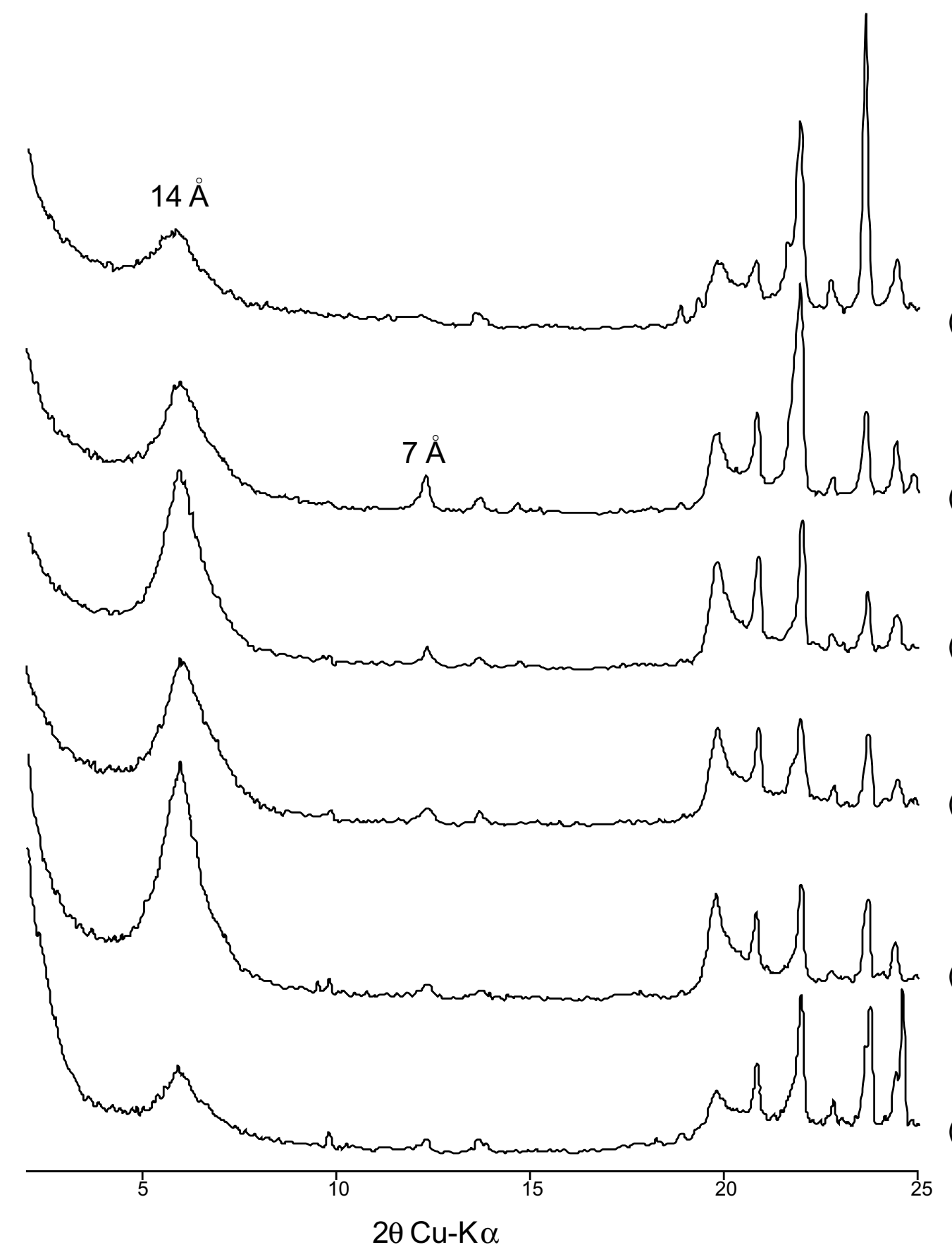

Fig. 3. XRD patterns of samples of the bulk ash. (a) R230 on March 31, 2000 (b) south of Showa Shinzan on April 2 (c) Nakatoya Community House on April 4 (d) Hanawa Lake Farm Hill on April 4 (e) Sobetsu on April 6 (f) near Konpira crater on September 26.

ethylene glycol solvation. Heating at $600^{\circ} \mathrm{C}$ for one hour made the basal spacing at $7 \AA$ disappear and the reflection at $14 \AA$ shift to about $10 \AA$. Based on the XRD analysis, smectite is the dominant clay and kaolin is a minor one in the fine fraction of the 2000 ash. The dominant clay mineral of the

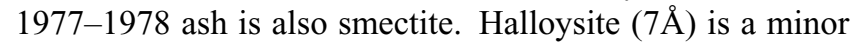
constituent (Kondo et al., 1979). The mineral assemblage and the trend of change in chemical composition of the 2000 ash are quite similar to those of the 1977-1978 ash shown by Matsuo et al. (1977).

It is generally acknowledged that rocks are depleted in $\mathrm{SiO}_{2}$ but enriched in $\mathrm{FeO}$ and smectite is formed through alteration by weakly alkaline water in the subsurface (e.g. Ossaka, 1968, 1982). The chemical characteristics and mineral assemblage of the 1977-1978 ash designate that the ash is an assortment of fresh pumice derived from ascending new magma and old volcaniclastics of the historic eruptions altered by weakly alkaline water in the subsurface at the summit crater (Matsuo et al., 1977; Kondo et al., 1979). Figure 5 shows relationship between the percentages of the LOI and the relative proportions of $\mathrm{SiO}_{2}$ to $\left(\mathrm{SiO}_{2}+\mathrm{Al}_{2} \mathrm{O}_{3}+\mathrm{FeO}\right)$ of the 1977-1978 ash and the essential products. Rocks become hydrated and LOI may increase as alteration progresses. Linear correlation between the LOI percentages and 

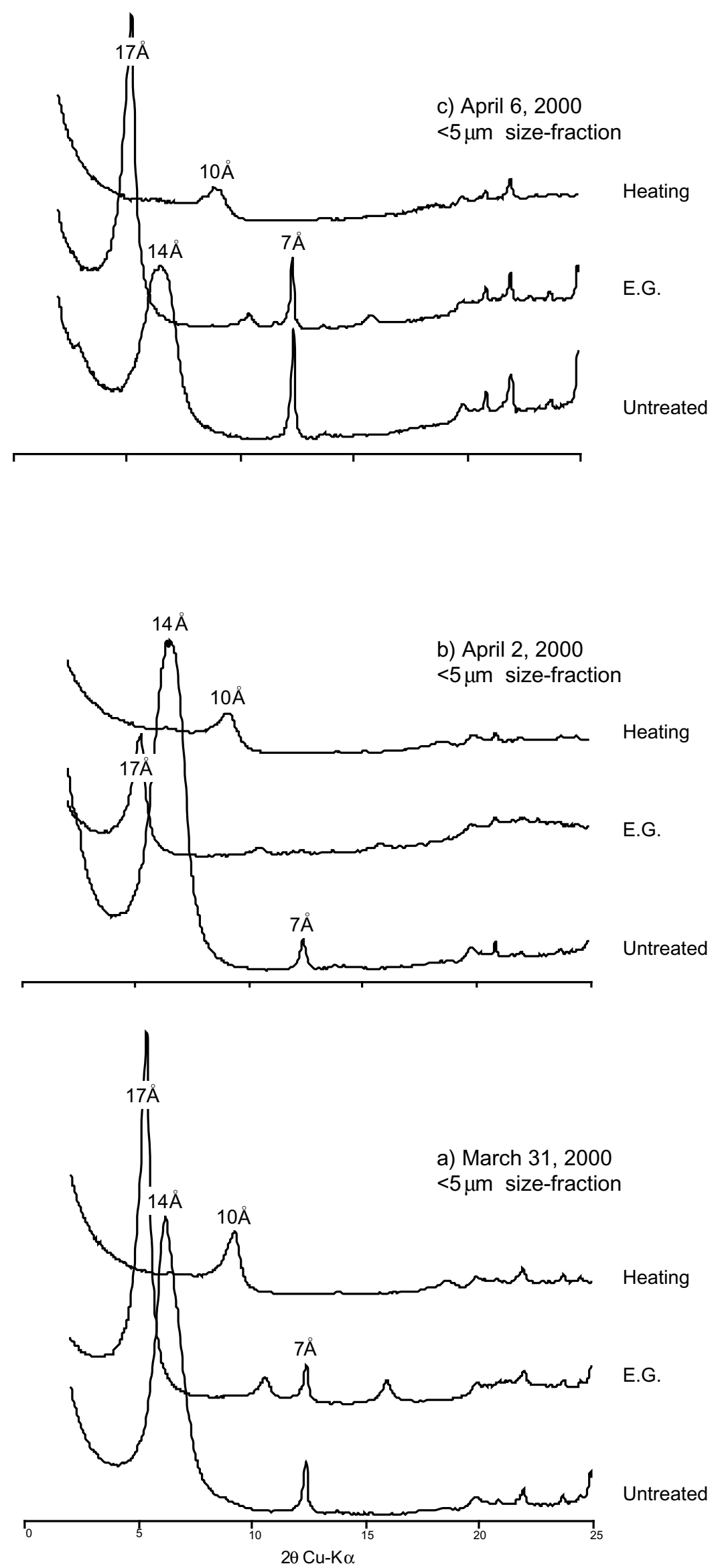

Fig. 4. XRD patterns of clay fraction of the representative ash. E.G.: ethylene glycol solvation Heating: heating at $600^{\circ} \mathrm{C}$ for one hour. 


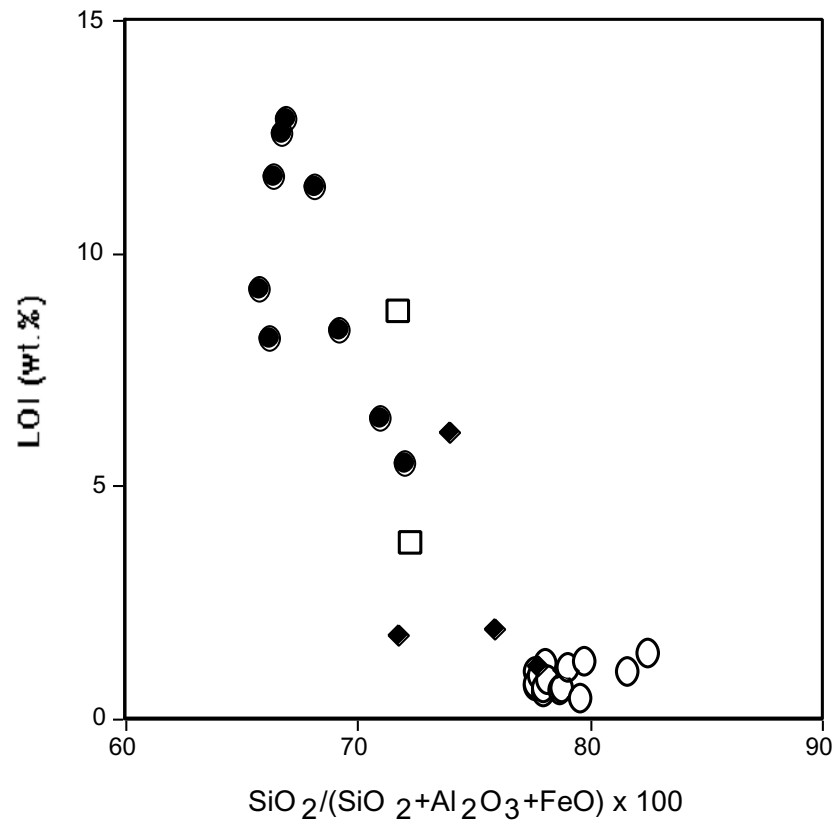

$\begin{array}{ll}\square & \text { The } 1977 \text { ash from Matsuo et al. (1977) } \\ \text { The } 1977-1978 \text { ash from Kondo et al. (1979) } \\ \text { The } 2000 \text { ash } \\ \text { Essential ejecta from Katsui et al. (1978) }\end{array}$

Fig. 5. Variation of LOI of the 2000 ash, the 1977-1978 ash and the essential product of the historic eruptions plotted against the ratio of $\mathrm{SiO}_{2}$ to $\left(\mathrm{SiO}_{2}+\mathrm{Al}_{2} \mathrm{O}_{3}+\mathrm{FeO}\right)$.

the relative proportions of $\mathrm{SiO}_{2}$ is clear, which shows that the essential products of the historic eruptions become depleted in $\mathrm{SiO}_{2}$ as the alteration progresses. The LOI percentages and the relative proportions of $\mathrm{SiO}_{2}$ of the 2000 ash are also plotted on the same alteration trend as the 1977-1978 ash (Fig. 5). These results indicate that the constituents of the 2000 ash are the older volcaniclastics altered in the subsurface environment and that they are more altered than those of the 1977-1978 ash are.

Kaolin is formed through alteration under weakly acidic condition or weathering. The XRD patterns (Fig. 3) reveal that the 2000 ash contained small amounts of kaolin but it contained in the September ash was less than that in the early stage of the 2000 eruption. Formation of the new craters continued for about one week from the beginning of the eruption and discharge of volcanic gases from some craters was main activity after that. These results suggest that kaolin in the 2000 ash is mostly derived from near the surface rather than the older volcaniclastics in the subsurface.

\section{Conclusions}

The chemical and mineralogical study of the 2000 ash of the Usu volcano provided us with important data on its nature and origin. No temporal variations in the chemical composition and mineral assemblage of the 2000 ash were observed during about half a year of the volcanic activity. The 2000 ash was highly depleted in $\mathrm{SiO}_{2}$ but enriched in $\mathrm{FeO}$ com- pared with the essential products of the historic eruptions. It was greatly hydrated and smectite was its major constituent. These characteristics are quite similar to those of the 19771978 ash. The results indicate that the constituents of the 2000 ash were old volcaniclastic materials of the historic eruptions highly altered in the shallow subsurface environment.

Acknowledgments. We would like to express our sincere thanks to Professor Hiromu Okada and all the staff of Institute of Seismology and Volcanology, Hokkaido University for their invaluable assistance in fieldwork. We are also grateful to all the members of Joint Universities Research Group and Japan Meteorological Agency for their help. Visiting Professor Bryndis Brandsdóttir of the Institute of Seismology and Volcanology of Hokkaido University is acknowledged for providing very helpful reviews.

\section{References}

Hirabayashi, J., T. Ohba, and K. Nogami, Chemical Composition of Volcanic Gases Associated with the 1991-1992 Activity of Shinmoe-dake, Kirishima Volcanoes, Japan, Bull. Volcanol. Soc. Japan, 41, 263-267, 1996 (in Japanese).

Ishikawa, T., Formation and change of Toya Hot Spring, BUTSURI-TANKO (GEOPHYSICAL EXPLORATION), 16, 27-37, 1963 (in Japanese with English abstract).

Katsui, Y., Y. Oba, K. Onuma, T. Suzuki, Y. Kondo, T. Watanabe, K. Niida, T. Uda, S. Hagiwara, T. Nagao, J. Nishikawa, M. Yamamoto, Y. Ikeda, H. Katagawa, N. Tsuchiya, M. Shirahase, S. Nemoto, S. Yokoyama, T. Soya, T. Fujita, K. Inaba, and K. Koide, Preliminary report of the 1977 eruption of Usu Volcano, J. Fac. Sci. Hokkaido Univ., Ser. IV, 18, 385-408, 1978.

Kondo, Y., T. Fujitani, Y. Katsui, and K. Niida, Nature of the 1977-1978 Volcanic ash from Usu Volcano, Hokkaido, Japan, Bull. Volcanol. Soc. Japan, 24, 223-238, 1979 (in Japanese with English abstract).

Matsuo, S., M. Kusakabe, H. Chiba, H. Ushiki, J. Ossaka, J. Hirabayashi, T. Abiko, K. Notsu, T. Ozawa, S. Aramaki, K. Sato, T. Hayashi, J. Sato, and N. Fujii, Geochemical Study on Ground Water, Thermal Water and Ash Fall Collected Immdiately after the 1977 Eruption of the Usu Volcano, Japan, Bull. Volcanol. Soc. Japan, 22, 201-220, 1977 (in Japanese with English abstract).

Mori, Y. H. and T. Ui, Crustal Deformation and Eruptic Activities of Mt. Usu in 2000, J. JSNDS, 19-3, 383-390, 2000 (in Japanese with English abstract).

Nogami, K., J. Hirabayashi, T. Ohba, and Y. Yoshiike, The 1997 phreatic eruption of Akita-Yakeyama volcano, northwest Japan: Insight into the hydrothermal processes, Earth Planets Space, 52, 229-236, 2000.

Okada, H., H. Mori, and H. Oshima, Bases of Successful Prediction of the Eruption of Mt. Usu, Japan, Abstracts of The Volcanol. Soc. Japan, 2000 No. 2, 22, 2000 (in Japanese).

Ossaka, J., Alteration of rocks in volcanic and hot spring area, Chinetsu, 17, 65-79, 1968 (in Japanese with English abstract).

Ossaka, J., Activity of volcanoes and clay minerals, J. Clay Sci. Soc. Japan, 22, 127-137, 1982 (in Japanese with English abstract).

Ossaka, J. and J. Hirabayashi, Clay minerals in volcanic ejecta, J. Mineral. Soc. Japan, 15, 223-238, 1981 (in Japanese with English abstract).

Ossaka, J. and T. Ozawa, The 1962-ejecta from Mt. Yake, Nagano-Gifu Prefectures and its Mechanism of Eruption, Bull. Volcanol. Soc. Japan, 11, 17-29, 1966 (in Japanese with English abstract).

Ui, T. and Geological party, Joint Obs. Team, 2000 eruption of Usu volcano: Chronology and disasters, Abstracts of The Volcanol. Soc. Japan, 2000 No. 2, 23, 2000 (in Japanese).

Ylagan, R. F., S. P. Altaner, and A. Pozzuoli, Hydrothermal alteration of a rhyolitic hyaloclastite from Ponza Island, Italy, J. Volcanol. Geotherm. Res., 74, 215-231, 1996.

Yokoyama, I., Y. Katsui, Y. Oba, and Y. Ehara, Usu-zan, its volcanic geology, history of eruption, present state of activity and prevention of disaster, Committee for Prevention of Disasters of Hokkaido, 254, 1973 (in Japanese).

K. Nogami (e-mail: knogami@ksvo.titech.ac.jp), J. Hirabayashi, Y. Nishimura, and A. Suzuki 